\title{
Party Spirit Made Flesh: The Production of Legitimacy in the Aftermath of the 2008 Sichuan Earthquake
}

\author{
Christian Sorace
}

\begin{abstract}
A B S T R A C T
This article argues that the Party retains a tradition of seeking to revitalize its legitimacy through demonstrations of benevolence and glory. The post-2008 Sichuan earthquake provided just such an opportunity to mobilize the discourse of "Party spirit" and display the willingness of cadres to suffer and sacrifice themselves on behalf of the people. In addition to being grist for the propaganda mill, these norms and expectations were implemented in concrete policy directives and work pressures. Local cadres, who were also earthquake survivors, started to suffer from exhaustion, insomnia, and depression. After high-profile suicides by several local cadres, the Party adopted a therapeutic discourse in order to address the psychological needs of individual cadres, though these gentler policies seem doomed to be short-lived.
\end{abstract}

$\mathrm{O}$ May 12, 2008, a 7.9 magnitude earthquake struck the Wenchuan region of Sichuan province. It resulted in over 85,000 fatalities, left 5 million people homeless, and disabled critical communication and transportation infrastructures. The catastrophe was prolonged as a result of multiple aftershocks, mudslides, and floods. The government's response was praised for allowing unprecedented media access to the earthquake zone and the emotional response of national leadership, most notably the compassionate tears of Premier Wen Jiabao. ${ }^{1}$

The party-state's monopoly on moral authority was complicated, however, inasmuch as "a tremendous surge of volunteers, civic associations, enterprises, and media from across the country donated their time, money and materials to the

${ }^{*}$ I wish to thank Geremie Barmé, Andrew Mertha, Joseph Mink, Anita Chan, Jonathan Unger, and the reviewers for their helpful comments and suggestions. I am also grateful for the opportunity to present an earlier version of this article at Cornell University's Contemporary China Initiative Lecture Series.

1. Bin Xu, "Grandpa Wen: Scene and Political Performance," Sociological Theory 30, no. 2 (2012): 114-29; Yi Kang, Disaster Management in China in a Changing Era (Berlin: Springer, 2014).

Electronically published May 9, 2016

The China Journal, no. 76. 1324-9347/2016/7601-0003. Copyright 2016 by The Australian National University. All rights reserved. 
relief and reconstruction effort."2 Although Party leaders lauded the compassion of the people, they were concerned by the proliferation of nongovernmental organizations (NGOs) and warned against the potential for foreign agents' infiltration and manipulation. The spontaneous self-organization and compassion demonstrated by ordinary citizens also encroached on the Party's terrain as provider for the Chinese people's welfare. ${ }^{3}$

The Party's moral authority was challenged on another dimension by reports on the collapse of poorly constructed schools that had caused the deaths of thousands of schoolchildren. These were disparagingly referred to as "toufu dreg schoolhouses." Allegations of corrupt deals between local officials and building contractors depicted profit-obsessed Party officials with an arrant disregard for life. The Party's claim to moral authority was imperiled by the protests of grieving parents. Under these political and symbolic pressures, it was imperative for the postearthquake reconstruction to display the dedication and compassion of Party officials.

This message was emphasized on earthquake-zone banners that read: "An earthquake doesn't care, the Party cares" (dizhen wuqing, dang youqing) and "be grateful to the mighty Communist Party for the new roads, new bridges, and new houses" (gan'en weida gongchandang, xin lu, xin qiao, xin zhufang). In official media reports, local residents were supposedly proclaiming: "without the Party, I would not be alive" (meiyou dang zuzhi, jiu meiyou wo de shengming). When earthquake survivors voiced discontent with the policies or process of the reconstruction, a "gratitude education" (gan'en jiaoyu) campaign was initiated to persuade people to adopt the correct attitude in relation to the Party's generosity (or to put it more cynically, 'stick to their lines'). ${ }^{4}$

From the Party's vantage point, within three years of reconstruction work it accomplished a "great leap in development" (kuayueshi fazhan) of public infrastructure and services, increased regional prosperity and job opportunities, and guaranteed all earthquake survivors new homes. In an editorial on the third an-

2. Shawn Shieh and Deng Guosheng, "An Emerging Civil Society: The Impact of the 2008 Sichuan Earthquake on Grass-Roots Associations in China," China Journal, no. 65 (2011): 181-94. See also Bin Xu, "Consensus Crisis and Civil Society: The Sichuan Earthquake Response and State-Society Relations," China Lournal, no. 71 (January 2014): 91-108; Jessica Teets, "Post-earthquake Relief and Reconstruction Efforts: The Emergence of Civil Society in China?," China Quarterly 198 (2009): 330-47; Yang Guobin, "A Civil Society Emerges from the Earthquake Rubble," Yale Global Online, June 5, 2008, http://yaleglobal.yale.edu/print/4739.

3. My argument draws inspiration from the following passage of Vivienne Shue: "The specific content of their meanings has been continually adjusted and altered to suit the needs of changing times. But the ideals of Truth, Benevolence, and Glory have been constantly renewed in Chinese discussions around the subject of good governance and in China's modern politics of state legitimation and opposition. These three were plainly visible as governmental claims to authority under Mao ... they remain central themes in the state legitimation project of the post-Mao era." Vivienne Shue, "Legitimacy Crisis in China?" in State and Societv in 21st Century China: Crisis, Contention, and Legitimation, ed. Peter Hays Gries and Stanlev Rosen (New York: Routledge, 2004), 50.

4. "China's Vision for Developing Sichuan's Post-earthquake Countryside: Turning Unruly Peasants into Grateful Urban Citizens,” China Quarterly 218 (June 2014): 404-27. 
niversary of the earthquake by the People's Daily writing team, the reconstruction was celebrated as a "miracle" (qiji) made possible due to the "faith" (xinnian) of the Communist Party. ${ }^{5}$ According the Party's discursive rationality, it had been able to achieve miracles through the mobilization of the "Party spirit" (dangxing) of its cadres. Due to the cultivation of Party spirit, cadres had been expected to place the people and Party above their own personal interest.

Scholars are apt to dismiss this Communist Party propaganda discourse as "obsolete and far-fetched." As Anne-Marie Brady observes: "Many China specialists seem to have taken it as an article of faith that the CCP government is doomed and the propaganda state is dead." ${ }^{\prime 7}$ Even scholars like Brady who note the importance of propaganda for "guaranteeing the CCP's ongoing legitimacy and hold on power" tend to dismiss the importance of its discursive content. ${ }^{8}$

I suggest that the content of Party propaganda is significant in the way it insistently reminds China's citizens that their well-being is the result of its benevolence. The Party's claim to benevolence in turn depends on the willingness of Communist Party cadres to sacrifice themselves for the Party and the people. The discursive logic of sacrifice, debt, and gratitude is the modular blueprint of Party legitimacy. In the place of "earthquake," one can insert "class enemy," "American imperialism," "SARS," "poverty," or whatever plays the role of antagonist at the time.

In the following section of this article, I will demonstrate how the Party engineered "glory" in the aftermath of the 2008 Sichuan earthquake by turning to Party spirit. The term Party spirit (dangxing) is wielded to demand from relevant cadres (ganbu) at such times a style of work premised on a lifelong commitment of submission to the Party. I suggest that this discourse of Party spirit exerts a grid-like network of norms, expectations, prohibitions, and pressures on such Communist Party cadres. The section of this article will provide examples of propaganda narratives of model cadres who reportedly were so dedicated to their reconstruction work at Wenchuan that they neglected their health, resulting in their untimely deaths. They follow a formula that stretches back to the Party vision of Maoist times in which "whatever smacks too much of the human creatureappetite, feeling, sensibility, sensuality, imagination, fear, passion, lust, self-interest, etc.-is purged and repressed so that the all-too-human is sublimated with vio-

5. Christian Sorace, "The Communist Party's Miracle? The Alchemy of Turning Post-disaster Reconstruction into Great Leap Development," Comparative Politics (July 2015): 479-98.

6. Huang Haifeng's argument that propaganda is mainly used "to signal the government's strength in maintaining social control and political order" downplays the Party's obsessive control over the wording and content of propaganda. The fact that propaganda may be badly written does not make it arbitrary. See Huang Haifeng, "Propaganda as Signaling," Comparative Politics (July 2015): 419, 420.

7. Ann-Marie Brady, Marketing Dictatorship: Propaganda and Thought Work in Contemporary China (Lanham, MD: Rowan \& Littlefield, 2009), 183.

8. Ibid., 1. 
lence into the superhuman and even inhuman realm" of Party spirit. ${ }^{9}$ In the aftermath of the earthquake, the creaturely frailties of "human nature" (renxing) were to be overcome, such as concern for personal safety and depression over the deaths of friends and family.

The article's third section demonstrates how the norms and expectations of Party spirit were conveyed in discourses, policy directives, work pressures, and punitive sanctions. The fourth and fifth sections trace how the discourse of Party spirit inscribed itself on the bodies of cadres, regardless of their individual convictions and moral dispositions. Local cadres who were also earthquake survivors) started to exhibit symptoms of exhaustion, depression, and post-traumatic stress disorder. The article will discuss why, after several cadres committed suicide, Party leaders partially changed course and responded with policy measures based on a therapeutic discourse of self-care targeting the cadre as an individual.

To capture the Party's discursive logic, the article draws from a significant body of Chinese textual material ranging from mass media accounts, published Party materials, and internally circulated Party work reports, in order to examine the effects of the Party's discursive and propaganda models on concrete policies and cadres' lives. My examination of these effects is based on over 18 months of fieldwork from January 2012 to August 2013, during which I conducted research in five municipalities, seven county seats, six rural townships, and seven villages affected by the 2008 earthquake. In the field, I conducted interviews with local cadres administratively ranked at the village, township, and county levels. For the majority of interviews, I was introduced to cadres through networks of friends, scholars, NGOs, and the cadres I had previously interviewed. Interviews varied in both duration and location, ranging from impromptu dinners, informal car trips, to formal discussions conducted in an office setting. I also draw upon interview transcripts conducted by local researchers.

My article does not claim that all cadres were saintly or pure. I frequently heard colorful rumors about cadre corruption and, on occasion, even witnessed villagers hurling abuse at cadres who in their eyes misappropriated funds and fiendishly profited from the reconstruction. The purpose of this article is not to vindicate or disprove such allegations but to show how the mechanics of Party legitimacy and the discourse of Party spirit continue to operate whether or not cadres are corrupt.

\section{THE DISCOURSE OF PARTY SPIRIT}

In his 1924 eulogy for Lenin, Stalin said, “Comrades, we Communists are people of a special mold. We are made of a special stuff." ${ }^{10}$ In the Soviet Union, the of-

9. Wang Ban, The Sublime Figure of History: Aesthetics and Politics in Twentieth Century China (Stanford, CA: Stanford University Press, 1997), 2.

10. J. V. Stalin, "On the Death of Lenin" (January 30, 1924), public translation available at https://www.marxists .org/reference/archive/stalin/works/1924/01/30.htm 
ficial term for this "special stuff” was partiinost' or "Party spirit," a term translated into Chinese as dangxing, literally, the "character" or "nature" of the Party.

The Communist Party employs the discourse of Party spirit to establish the proper relationship between the individual cadre and the Party organization. ${ }^{11}$ Admission into the Chinese Party requires candidates to swear an oath in front of the Party flag in which they declare that they are willing to "be ready at all times to sacrifice ... all for the Party and the people, and never betray the Party."12 In article 3, clause 3 of the Party Constitution, Party members are required to "subordinate their personal interests to the interests of the Party and the people" and in doing so be "the first to bear hardships and the last to enjoy comforts."13 At the core of how the Party understands and legitimates itself is the differentiation between "Party spirit" (dangxing) and "human nature" (renxing). To put it simply: it is the collective over the individual, the politically engineered over the personally motivated. According to Liu Shaoqi's classic 1939 handbook How to Be a Good Communist, "unhesitating readiness to sacrifice personal interests and even one's life for the Party and for the proletariat and for the emancipation of the nation and of all mankind-this is one expression of what we usually describe as "Party spirit," "Party sense," or "sense of organization." It is the highest expression of communist morality, of the principled nature of the party of the proletariat and of the purest proletarian class-consciousness."14

From the perspective of historical materialism, communist morality does not arise from an innate goodness in human nature; it has to be learned. ${ }^{15}$ A cadre's Party spirit is the product of submission to Party discipline, management, and

11. It is important to note that the definition of Party spirit has a complex and contested history that can only be mentioned in passing here. During the Mao era, Party spirit manifested the "class character" (jiejixing) of the Communist Party. After Mao's death and the abandonment of class struggle as the Party's guiding platform, theorist and propagandist Hu Qiaomu presciently warned in 1982: "If we leave class struggle and discuss the character of the people [renminxing], we will have lost our direction." Without the ideology of class struggle as its animating principle and goal, Hu worried that Party spirit would be emptied of its ideological content, vitality, and charisma. See Hu Qiaomu, "Guanyu xinwen gongzuo de dangxing he 'renminxing' wenti" [Regarding the problem of Party spirit and popular character in news work], in Hu Qiaomu ji di er juan [The collected works of Hu Qiaomu] (Beijing: Renmin chubanshe, 1993), 2:527.

12. The Party Oath can be found in Chinese at http://cpc.people.com.cn/GB/64156/65682/4440819.html.

13. A complete English version text of the Constitution of the Chinese Communist Party is available at http://english.cpc.people.com.cn/206972/206981/8188090.html.

14. Liu Shaoqi, How to Be a Good Communist (1939), public translation available at https://www .marxists.org/reference/archive/liu-shaoqi/1939/how-to-be/ch06.htm.

15. In Chinese philosophy, there is a deep-rooted conviction in human malleability and the importance of education in shaping one's moral character. In the terse words of Xunzi, "people's nature is bad. Their goodness is a matter of deliberate effort." Xunzi compares human nature to "crooked wood" that must be straightened through the "transforming influence of teachers and models." The CCP adopted a similar worldview that continues to shape the Party's propaganda efforts and governance strategies. Xunzi, The Complete Text, trans. by Eric L. Hutton (Princeton, NJ: Princeton University Press, 2014), 248. For an overview of "exemplarity" in Chinese statecraft, see Børge Bakken, The Exemplary Society: Human Improvement, Social Control, and the Dangers of Modernity (Oxford: Oxford University Press, 2000). 
molding. ${ }^{16}$ After induction into the Party, a cadre's life belongs to the Party similar to how St. Augustine conceptualized the body as a vessel of the Lord. ${ }^{17}$ If Party spirit is the Word, it is engraved on the flesh through a network of organizational power, training sessions, rituals, confessional practices, exhortations, media hype, promotion incentives, and punishments. ${ }^{18}$ The Party's ideological and organizational apparatuses are designed to produce, cultivate, and maintain the "special stuff" of Party spirit in the body of the cadre. ${ }^{19}$

This lifelong cultivation of the individual cadre is not primarily for personal career advancement; it is for the glory of the Party, what Ken Jowitt, a Soviet specialist, referred to as the signature "charismatic impersonality" of the Party organization in Leninist regimes. ${ }^{20}$ Through the mechanism of cadre sacrifice in particular, Party spirit is transferred from the individual to the organization in the form of glory. In lieu of an electoral mandate to rule, Party legitimacy requires the constant production, exaltation, and acclamation of glory. ${ }^{21}$

Consequently, Party legitimacy can benefit from natural disasters, which provide opportunities for the mobilization of Party spirit and display of benevolence. ${ }^{22}$

16. Frank Pieke, The Good Communist: Elite Training and State Building in Today's China (Cambridge: Cambridge University Press, 2009).

17. For Augustine, God is the ultimate and only reference point through which human life is meaningful: "For just as that which gives life to the flesh is not something derived from the flesh, but something above it, so that which makes the life of man blessed is not something derived from him, but something above him." On this basis, Augustine argues that a Christian should not seek praise and flattery for their good deeds, "for you are not anything at all in yourself." Similarly, under Communist Party rule, according to organizational principles, cadres are not permitted to act in their own name and enrich themselves. A cadre's purpose is to manifest the glory of the Party. Augustine, The City of God against the Pagans, ed. R.W. Dyson (Cambridge: Cambridge University Press, 1998), 961. For a selective list of political theological readings of the Communist Party, see David E. Apter and Tony Saich, Revolutionary Discourse in Mao's Republic (Cambridge, MA: Harvard University Press, 1994); Ban Wang, "In the Beginning Is the Word: Popular Democracy and Mao's Little Red Book," in Mao's Little Red Book: A Global History, ed. Alexander C. Cook (Cambridge: Cambridge University Press), 266-77; Michael Dutton, "Mango Mao: Infections of the Sacred," Public Culture 16, no. 2 (2004): 161-87; Christian Sorace, "Saint Mao," Telos 151 (Summer 2010): 173-91.

18. My understanding of the flesh as a modern political category and production site of legitimacy is inspired by the work of Eric Santner: The Royal Remains: The People's Two Bodies and the Endgames of Sovereignty (Chicago: University of Chicago Press, 2011), and The Weight of All Flesh: On the Subject-Matter of Political Economy (Oxford: Oxford University Press, 2015).

19. I am drawing from Franz Schurmann's classic argument that the Party governs its own members through the dual mechanisms of ideological and organizational control; see Ideology and Organization in Communist China (Berkeley: University of California Press, 1968).

20. Ken Jowitt, New World Disorder: The Leninist Extinction (Berkeley: University of California Press, 1993).

21. The term "acclamations of glory" is borrowed from Giorgio Agamben, The Kingdom and The Glory: For a Theological Genealogy of Economy and Government (Stanford, CA: Stanford University Press, 2011). For a discussion of "glory" as a pillar of Party legitimacy, see Shue, "Legitimacy Crisis in China?"

22. There are also other benefits to crisis governance: "Deftly employed, the rhetoric of crisis helps to legitimate extraordinary interventions by social and political elites, subvert the standard bureaucratic procedures that characterize normal politics and create political space for extraordinary mobilizations of resources to overcome challenges." See Patricia Thornton, "Crisis and Governance: SARS and the Resilience of the Chinese Body Politics," China Journal, no. 61 (2009): 26. 
Party propagandists are indeed quite candid about the "utilization of natural disasters as a focus for central and local government propaganda work. CCP propaganda specialists recommend this as a particularly useful means of raising governmental approval ratings." ${ }^{23}$ Although the Party's legitimacy benefits from high approval ratings, it does not require this (otherwise, how can we explain the Party's seemingly stubborn commitment to narratives and models that are no longer appealing or believable in the eyes of many Chinese citizens?). Instead of a hazy notion of public approval, I suggest that the real locus of Party legitimacy is the production of its benevolence and glory.

\section{PARTY SPIRIT IN THE WORDS OF THE DYING}

Confucius declared, "When a bird is about to die, his song is sad; when a man is about to die, his words are true." 24 But the poignant aura of last words is diminished if these are ventriloquized, fabricated, or clichéd. How then to explain Party propaganda in which a model cadre's last words are slogans that express gratitude for the life granted by the Party?

One answer comes from Haiyan Lee's description of hagiographical accounts of People's Liberation Army (PLA) martyrs as a propaganda genre. "The moment of death is always formulaically stylized and saturated with ideological signification. Invariably Mao's instruction or the Party's bounty would flash across the hero's mind as he (sometimes she) lies dying and, whenever possible, the last breath is expended on revolutionary slogans. There is absolutely no room to question the motivation for the sacrifice or the meaning of death." 25 Lee argues that the "aestheticization and de-individualization of death" produces the effects of what she calls the "military sublime." ${ }^{26}$ A nearly identical narrative structure and repertoire of tropes are used in propaganda accounts of the model Party cadre, which alongside the PLA martyr contribute to the Communist Party's "charisma of power." 27

A second answer is that the purpose of Communist Party propaganda is not the authenticity and accuracy of its representation of reality; it is supposed to be idealized. According to Børge Bakken, in traditional Chinese culture, authority is represented in models and normative ideals that are to be studied and emulated. The Party continues this tradition by elevating model cadres, soldiers, workers,

23. Brady, Marketing Dictatorship, 188.

24. In the commentary on his translation of The Analects, Simon Leys compares this line to Shakespeare's Richard II: "The tongues of dying men / Enforce attention, like deep harmony." See Confucius, The Analects, ed. Michael Nylan, trans. Simon Leys (New York: Norton, 2014), 35.

25. Haiyan Lee, "The Charisma of Power and the Military Sublime in Tiananmen Square," Lournal of Asian Studies 70, no. 2 (2011): 409.

26. Ibid., 406.

27. Ibid., 399. 
work units, urban communities, and whomever or whatever it regards as useful for exemplifying both its authority and the wisdom of its policies. However, Bakken also suggests that "the fading power of the model is linked to the general crisis of power and problems of legitimacy for the present regime." 28 Whereas models instilled devotion during the Mao era, ${ }^{29}$ what is their role in an age of political disenchantment, public cynicism, and Party corruption? ${ }^{30}$ What becomes of a political system based on moral exemplarity and emulation, when the authority of models is no longer believed in?

The rational response would seem to be: "If the models are no longer working, stop using them." However, such a seemingly practical suggestion is insensitive to what Geertz referred to as the "inherent sacredness of sovereign power" and the need for whoever is in power to maintain it. ${ }^{31}$ For all of the Communist Party's adaptability, fluidity, and ruthless pragmatism, it cannot divest itself of propaganda models without losing the symbolic support of its authority. Xi Jinping seems to intuitively grasp the indispensability of the appearance of faith especially in an age of rampant corruption and disbelief.

One such model cadre whom Xi Jinping has cited as an inspiration was a countylevel Party secretary half a century ago named Jiao Yulu, whose life and death became famous as a model throughout China during the 1960s. Jiao had been assigned to serve as county Party secretary of Lankao county in Henan province in 1962, during the aftermath of the Great Leap Forward. Agriculture in parts of the county were endangered by spreading sand dunes, and Jiao's love for the people motivated him to forgo rest despite severe pain he felt in his side, while he led the masses to remove the dunes. According to Charles Laughlin, "consumed by his work, Jiao Yulu is not even aware of the nature and seriousness of his illness and seeks no medical attention until he is incapacitated." 32 In the moments before his death, Jiao can only think of the Party and the suffering people of Lankao. His last recorded words are: "I only have one request after I'm gone; I want the Party to send me back to Lankao and bury me in one of the sand dunes. I might be dead, but I want to make sure you get those dunes under control."33

28. Bakken, Exemplary Society, 194.

29. Anita Chan, Children of Mao: Personality Development and Political Activism in the Red Guard Generation (London: Macmillan, 1985).

30. Wu Si, Qian guize: Zhongguo lishi zhong de zhenshi youxi [The hidden rules: Real games of Chinese history] (Shanghai: Fudan daxue chubanshe, 2009); Jiwei Ci, Moral China in the Age of Reform (Cambridge: Cambridge University Press, 2014); Xiaoying Wang, "The Post-Communist Personality: The Spectre of China's Capitalist Market Reforms," China Journal, no. 47 (January 2002): 1-17.

31. Clifford Geertz, "Centers, Kings, and Charisma: Reflections on the Symbolics of Power," in Rites of Power: Symbolism, Ritual, and Politics since the Middle Ages (Philadelphia: University of Pennsylvania Press, 1985), 13-38.

32. Charles A. Laughlin, Chinese Reportage: The Aesthetics of Historical Experience (Durham, NC: Duke University Press, 2002), 259.

33. Ibid. 
The Jiao Yulu story has been propagated at various critical political junctures in the past few decades. In the wake of the armed suppression of the Tiananmen protests, then Standing Committee Member of the Politburo Li Ruihuan launched a campaign in the early 1990s to study the "spirit of Jiao Yulu." According to Geremie Barmé, Jiao Yulu "was an icon aimed at reconciling the masses with the party by convincing them that there are-or at least were-good and incorruptible cadres."34 A 1991 film about Jiao Yulu was a box office success and reportedly moved people to tears.

In $1990 \mathrm{Xi}$ Jinping composed a classical-style poem called "Recovering the Memory of Jiao Yulu" in which he praised Jiao as a model and kindred political spirit. ${ }^{35}$ One verse reads: "As I yearn for you one night after another / Your heart and mine are cleansed together." ${ }^{36}$ Later, as Party general secretary, Xi exhorted county-level cadres to "compare [themselves] to and emulate the virtuous" model of Jiao Yulu. ${ }^{37} \mathrm{Xi}$ has also conducted multiple trips to Lankao county and has remarked that "each time I step onto the soil of Lankao, I become emotional."

After the Sichuan earthquake, propaganda groups were organized to collect stories of "progressive model cadres" who sacrificed themselves like Jiao Yulu. ${ }^{38}$ Each story conforms to a standard story line in which the cadre prioritizes the reconstruction mission above any personal considerations. Party spirit defeats the human tendency to grieve and feel self-pity. With tremendous fortitude, the cadre does not spend time openly mourning dead relatives or consoling those who survived. Dedicated to work, the cadre compromises his or her health, ignores medical advice, falls ill, ignores the doctor's advice to rest, checks out of the hospital, returns to work, and exacerbates the illness to the point of death. The deathbed scene provides a denouement in which the cadre's last words are work instructions to fellow comrades or an expression of gratitude to the Party.

Such stories are supposed to be constructed out of real characters. One week before the earthquake, Yu Zhaorong, chair of the Wenchuan County People's Consultative Conference, was diagnosed with pulmonary heart disease and high

34. Geremie R. Barmé, In the Red: On Contemporary Chinese Culture (New York: Columbia University Press, 2000), 107-8.

35. The $c i$ was also a poetic form favored by Mao Zedong. Indeed, Mao's song lyrics were even set to music and sung during the Cultural Revolution. Xi's poem recently made headlines during Xi's state visit to the United Kingdom in October 2015 when the Chinese embassy arranged for a British student to recite Xi's poem as a tribute of respect. "Xi Jinping: China Has Taught UK Schools Discipline—and Has Learned about Play,” Guardian, October 22, 2015, http://www.theguardian.com/world/2015/oct/22/xi-jinping-china-taught-uk -schools-discipline-learned-about-play.

36. Ibid.; the Chinese original can be found on Baidu at http://baike.baidu.com/view/12514523.htm.

37. "Xi Jinping chongfang lankao: Jiao Yulu jingshen shi yonghengde" [Xi Jinping returns to Lankao: The Jiao Yulu spirit is eternal], Xinhua, March 17, 2014, http://news.xinhuanet.com/politics/2014-03/17 /c_119810080.htm.

38. Zheng Degang, "Kangzhen jiuzai bairi: 67 ming ganbu yin linzhen tuisuo deng xingwei bei chufen" [One hundred days of earthquake resistance and disaster relief: 67 cadres disciplined for getting cold feet], Renmin ribao, August 19, 2008. 
blood pressure. When the earthquake struck, he reportedly canceled his planned medical treatment in order to devote himself to relief and reconstruction work. According to a report of the Wenchuan county Party Organization Department, $\mathrm{Yu}$ Zhaorong explained his decision to forgo medical treatment in the language of Party spirit: "I am a Communist Party member; I am a cadre the Party has cultivated for many years; during the moment of calamity, I must not escape right before the battle." ${ }^{39}$ The implication is that the cadre no longer has a selfhood to preserve outside of the one cultivated by the Party. In the weeks following the earthquake, the narrative was that Yu worked overtime, slept nights in his car, and ate only sparse rations. Even after he collapsed at his post and was forced to check into a hospital, he returned to work while sick. The report also depicts Yu's stoic internalization of grief over the death of his son-in-law: "He could only allow his tears to fall toward his heart, and did not ask anything from the organization."

Wang Jihong, former Wenchuan county party standing committee member and head of the Wenchuan county discipline inspection committee, was reported to have followed a similar pattern. When the earthquake struck, he was in the hospital due to intestinal hemorrhaging. Immediately after the quake, according to the narrative, he discharged himself so he could participate in emergency evacuation work throughout Wenchuan's remote and scattered localities:

He was still concerned with work in his heart; his left hand inserted his intravenous drip into his arm, while his right hand clasped his cell-phone to his ear, and in a feeble voice he exhorted his comrades in the Discipline Inspection Commission office: "My illness is not serious. You must not allow comrades to visit me in Chengdu. In the next two days, there will be bids for the reconstruction projects. We must send specialists to supervise. There can be absolutely no mistakes. We must organize a study session of the Party Center's four important documents on fighting corruption. We must make sure everything arrives at its place." Two minutes after hanging up the phone, his breath became hurried and his complexion pale as his pulse disappeared, without time to utter one sentence to his family before he passed away. ${ }^{40}$

The theme of self-sacrifice is not limited to death. Huang Shunquan, head of a village located in Pengzhou, was helping villagers transport cement needed for re-

39. Wenchuanxian ganbu duiwu zhuangkuang gongzuo huibao [Wenchuan county cadre ranks situation work report]. I acquired this document from an internal archive within the Sichuan Party School, and its identifying author and document serial number have been removed. It is likely that it originated from the Party's organization department.

40. Wenchuanxian jiwei jianchaju (Wenchuan county discipline inspection commission supervisory office), "Zuo dang de zhongcheng weishi, dang qunzhong de tiexin ren, Wenchuanxian jiwei jianchaju yong xingdong quanshi jijian ganbu de biaozhun" [To serve as a loyal guardian of the Party and person intimate with the masses: Using actions to perform the standards of a disciplinary inspection cadre], undated document, from Sichuan Party School archive. 
construction of people's houses when his vehicle collided with a truck on a mountain road. According to a report from his Party branch, while attempting to "ensure the cement did not spill," Huang's left leg was crushed beneath the wheel of a truck and required amputation. In the hospital, Huang's daughter allegedly complained that even after the accident "our family issues are not as important as helping villagers. Even right now, he is eager to leave the hospital and return to work." 41

These exemplary stories were also strategically deployed for "stability maintenance" (wei wen) work-a Party keyword that designates the importance of maintaining social order and preventing public protests above all else. ${ }^{42}$ In Qingchuan county, Muyu middle school collapsed, causing several dozen injuries and deaths. According to a work report of the county mass work bureau, parents mourning the deaths of their children started to demand that county officials investigate the allegedly substandard construction quality of the schools that collapsed on their children. In order to placate their outrage, bureau chief Wang Shikun reportedly conveyed to the protestors that even though many members from his own family died, he did not abandon his post. A small work team was organized and dispatched to each of the victims' families in order to carry out "thought work" (sixiang gongzuo) and to "calm the situation." According to the report, "no cadre had requested a leave of absence or left their post due to the death of family members or personal injuries. ... Because of the long period on the road under the scorching sun without a change of clothing and nowhere to shower, one after another, to different degree, everyone fell ill, but no one shrank from the task." 43 The clear message was that the disaster victims should be grateful for the Party's sacrifice on their behalf, while indirectly delegitimizing their basis for complaint. At the same time, another message was sent to the bureau's administrative superiors that the county bureau's cadres had spared no personal cost in preventing a mass protest.

\section{“EATING BITTERNESS" IN THE AFTERMATH OF THE EARTHQUAKE}

The implausibility of these propaganda models would seem to confirm that the propaganda apparatus no longer is effective and suggests why people no longer

41. Yu Zaigu and Li Yang, "Wei bao chongjian wuzi Pengzhou shi cun zhuren Huang shunquan shoushang jiezhi” [Protecting reconstruction materials Pengzhou Muncipality village head Huang Shunquan sustained injuries that required amputation], Chengdu wanbao, October 27, 2008, http://sichuan.scol.com.cn/sczh /20081027/2008102770332.htm.

42. Xie Yue, "The Political Logic of Weiwen in Contemporary China," Issues \& Studies 48, no. 2 (2012): 1-41.

43. Zhonggong qingchuan xianwei qunzhong gongzuo ju (Qingchuan county Party mass work bureau), “Guanyu bao song '5.12' dadizhen wo xian xinfang ganbu suo zuo gongzuo de bao gao" [Work report regarding county letters-and-visits cadres’ work following the great May 12 earthquake], internal document, June 5, 2008. 
pay serious attention to Party propaganda. The Party leadership nevertheless habitually turns to this modus operandi. And in addition to seeking to bolster legitimacy (no matter how clumsily), this propaganda exerts pressure on the lives of cadres, regardless of their personal convictions. Especially during political campaigns and emergency mobilizations, the discourse of Party spirit defines the parameters in which cadre political performance is evaluated, praised, or punished.

In the aftermath of the 2008 Sichuan earthquake, local Party cadres were required to put their Party spirit into practice when engaging in rescue and relief efforts alongside the military. Their tasks involved the relocation of survivors into temporary shelters, the distribution of relief goods, epidemic prevention, and the recovery and removal of bodies. In addition, in order to initiate postquake reconstruction, local cadres in tandem with "provincial partners" (duikou zhiyuan) formulated and implemented reconstruction plans. This involved a range of tasks from housing reconstruction to medium- to long-term economic planning. At each stage of this process cadres were expected to manifest the Party spirit of "tireless struggle" and to "fear no sacrifice." ${ }^{4}$ They were expected to do so even though many of these cadres were earthquake survivors who had lost their houses and loved ones.

In a speech delivered a year and a half after the earthquake, in early 2010, Wenchuan county Party Secretary Qing Lidong praised local cadres as people who were willing to "engage in work an ordinary person would not be willing to take on and to eat bitterness that ordinary people are not capable of eating." 45 A capacity to endure suffering is, in the Party's narrative, a distinguishing characteristic of the Communist Party cadre.

Party spirit requires the suppression of human nature. Internal Party documents and department work reports unambiguously stipulated that during disaster rescue operations "cadres must always first rescue others" before family members and friends. ${ }^{46}$ Likewise, when dispensing relief materials, "cadres must first think of the broad masses" before considering their own needs. According to an interview with a leading Wenchuan county cadre, the "cadre evaluation standards for postearthquake work were extremely strict. They were first and foremost to remain side-by-side with the masses. If the masses still lived in tents,

44. Wang Bin, "Zai shi jie xianwei di 32 ci changwei (kuoda) huiyishang de jianghua" (speech given at the 32nd meeting of the tenth county standing committee enlarged conference), September 5, 2008.

45. Qing Lidong, "Pa poshang kan zhua zhongdian, xushi tupo cu kuayue" [Climbing up a slope on the threshold of grasping the important points, store up power to break through and step across], Zai jiakuai tuijin shi da zhongdian gongzuo dongyuan huishang de jianghua (speech given at the conference for the accelerated promotion of 10 large important points work mobilization conference), di 5 qi, zongdi 96 qi (2010).

46. Wenchuanxian ganbu duiwu zhuangkuang gongzuo huibao. 
you had to live in a tent. If the masses didn't have tents, you couldn't have a tent. If the masses didn't have relief supplies, such as bottled water and dried goods, you could not have any relief supplies." ${ }^{47}$ A professor from Dujiangyan Municipality Communist Party School explained that if cadres complained about "eating bitterness" such as exhaustion, work pressure, and low wages, their superiors would admonish them, asking, "Why did you join the Party if you wanted comfort or money?"48

For cadres who failed to display Party spirit, the Party availed itself of disciplinary measures and rhetorical denunciations. Organizational sanctions such as demotions or expulsion from the Party were meted out to cadres caught "leaving their work post without permission," "getting cold feet," and "shirking responsibilities." 49 A grassroots cadre from Qingchuan explained that "decisions to fire errant cadres were ordered by higher level officials. Any cadres not at their work posts would be fired; if a cadre first went to check on his children, he would be fired." ${ }^{50}$ When I asked him if he thought that the policy was extreme, he argued that these "political sacrificial objects" were necessary to reinforce "positive models of behavior." When I asked the Dujiangyan Party School professor about these punishments, he responded, "While it is totally understandable from the perspective of human nature to be afraid of rockslides and aftershocks, and to want to make sure your loved ones are okay, Party spirit demands that you put your job before everything else."

The discourse of Party spirit also underpinned the decision to transform postdisaster reconstruction into what planning documents described as a model of "great leap development." That is to say, the Party's goal was to accomplish 20 to 30 years of development within two to three years of reconstruction, a policy that rested totally on the mobilization and self-sacrifice of cadres. The ambitious postquake goals and timeframes required cadres to expend themselves in the project of reconstruction. As a consequence, cadres were expected to work on little sleep. The constant work pressures and lack of rest were reinforced with slogans such as "white plus black" (bai jia hei) (day and night) and "five plus two" (wu jia er) (weekday and weekend), which in current vernacular translates to "24/7" dedication and availability. The idea that development would be paid for with the flesh of individual cadres was explicitly rendered in the following

47. Interview, Wenchuan county seat, March 2013.

48. Interview, January 2013.

49. Wang Bin, "Zai zhonggong wenchuan xianwei shi jie qi ci quanti (kuada) huiyi shang de jianghua" (speech given at the seventh meeting of the entire tenth county standing committee enlarged conference), September 5, 2008.

50. Interview with township official, Qingchuan, May 2013. 
Party slogan: "Shed blood and sweat but not tears; shed skin, shed flesh, but do not fall behind!" (Liuxue liuhan bu liulei, diaopi diaorou bu diaodui). ${ }^{51}$

\section{THE FRAGILITY OF HUMAN NATURE}

The campaign-style mobilization of Party cadres who were earthquake survivors quickly resulted in symptoms of stress, exhaustion, and depression. A survey conducted in 2009 by the Dujiangyan Municipal Party School of 3,000 grassroots cadres revealed that in the aftermath of the earthquake 86 percent of respondents suffered from insomnia; 78 percent frequently experienced "dread" and "restless anxiety"; 73 percent were afraid of aftershocks and found it difficult to concentrate; 78 percent felt downcast, sorrowful, and depressed; and 77 percent reported that they were irritable and quicker to lose their temper. Overall, the report concluded that the majority of local grassroots cadres were in a state of "physical and emotional exhaustion" 52 that resembles what Arthur Kleinman referred to as the "somatic idioms of distress" 53 in a political culture reluctant to acknowledge psychological vulnerability.

Research by Chen Qiu and Yan Qianmin reported that the deteriorating psychological conditions of these local grassroots cadres were invisible within a system that took for granted their structural role and expected their self-sacrifice. ${ }^{54}$ The report was based on a survey conducted from November through December 2008 , in which a majority of respondents described themselves as suffering from "depression," "obsessive compulsive symptoms," "anxiety," "panic," "somatoform disorders," and other "nervous disorders." They reported symptoms of forgetfulness, lack of energy, inability to control temper, and lack of hope for the future. An estimated 15 percent reported entertaining the thought of suicide.

After the earthquake, work pressure did not allow cadres to spend time with their families, which contributed to an increased sense of isolation and guilt. According to the aforementioned report, "because of the intensity of work it's dif-

51. "Feixu shang da xie Qingchuan-Qingchuanxian kexue tuijin zaihou huifu chongjian jishi” [Writing Qingchuan on the ruins-Qingchuan county scientifically advancing postdisaster restoration and reconstruction record of events], Sichuan ribao, May 5, 2010, http://sichuandaily.scol.com.cn/2010/05/05 /2010050563722402441.htm.

52. Dujiangyanshi dangxiao (Dujiangyan Communist Party school), "Huifu, fazhan, chuangxin: 2009 nian zaihou chongjian youxiu yanjiu wenji xuanbian" [Reconstruction, development, innovation: Selected works of excellent research reports regarding the 2009 postdisaster reconstruction situation], internal publication, 2009, 5-8.

53. Arthur Kleinman, "Neurasthenia and Depression: A Study of Somatization and Culture in China," Culture, Medicine, Psychiatry 6, no. 2 (1982): 117-90.

54. Chen Qiu and Yan Qianmin, “Zaihou wenchuan jiceng ganbu xinli jiankang zhuangkuang diaocha ji tiaoshi duice yanjiu" [Postdisaster Wenchuan grassroots cadres psychological health situation investigation and proposed remedies], Xinan minzu daxue xuebao [Southwestern University for Nationalities journal] 2 (2011): 85-89. 
ficult for cadres to show concern for their own families and close relatives; many cadres experience guilt and blame themselves for neglecting their families." ${ }^{15}$ These unresolved tensions between Party spirit and human nature were felt in pangs of guilt and psychological torment.

To overcome their depression, according to PRC publications, local cadres reportedly relied on the language of Party spirit and demanded from themselves "willpower to overcome difficulties in order not to fail to live up to the nation and people's expectations and compassion and not let down the earthquake survivors who lost loved ones." ${ }^{\text {"5 }}$ Some cadres did seek to live up to the Party's image. A township Party secretary whose daughter had died when the local school collapsed told me, "At first I was numb and didn't want to do anything. Then, I thought to myself it is a natural disaster, many people suffered the same fate, and we have received the country's support, so I need to excel at my work and pull myself together. I've kept working, but sometimes in the middle of the night I think of these things and can't fall back asleep." ${ }^{57}$ When I asked him whether he was angry over the shoddy construction materials used in the school building that collapsed on his daughter, he stared into the distance and shook his head. His role as a Party cadre prohibited public articulation of grief (especially to a foreign researcher) that might contradict the Party line.

In summer 2008, the head of the Mianyang Municipal Party School and Administrative Management School conducted a series of interviews with township-level Party secretaries from Beichuan county to record their experiences during the earthquake. In June 2008, he interviewed a township-level cadre whom the interview transcript describes as ill at ease, compulsively smoking, and lapsing into inaudible mumbles and long silences. The cadre recounted personal traumas, including how he identified the corpse of his wife by her hair because her face was unrecognizable, and the moment he heard his mother calling for help from beneath a collapsed building but realized that he could not rescue her without the proper machinery. ${ }^{58} \mathrm{He}$ did not elaborate upon the death of his daughter. Disregarding his personal tragedy he was assigned to emergency patrols between Beichuan county seat and administratively subordinate local townships. ${ }^{59}$ His interview responses oscillated between intense self-hatred and blame for the death of his family and Party language that "personal matters are insignificant compared to those of the country." ${ }^{\circ 0}$ At one point, he recounted the story of another

55. Chen and Yan, "Ganbu xinli," 88.

56. Ibid.

57. Interview with village Party Secretary, Yingxiu, June 2012.

58. A Jian, Zai nanzhong: Shendu fangtan beichuan xiangzhen shuji [In the midst of difficulty: In-depth interviews with Beichuan Township Party secretaries] (Beijing: Renmin wenxue chubanshe, 2009), 285.

59. Ibid., 277.

60. Ibid., 279. 
local Party secretary who fortunately was sitting next to a water cooler when the building collapsed and thus managed to stay alive for days until he was rescued: "After the military police pulled him from the rubble, he immediately threw himself back into work." 61 The interview transcript concludes with an update from January 2009 when the cadre was visited at a mental health clinic (jingshen weisheng zhongxin) where he had been admitted for depression. A month later he returned to work, and his demeanor at work was described by a fellow cadre as silent for hours, head in hands, only occasionally looking up to say, "My wife, daughter, and mother are gone. At night I can't sleep ... "

This was not an anomalous case. I obtained an internal Party organization Excel spreadsheet that lists the postearthquake situation of over 2,300 cadres from Beichuan county and its subordinate townships and villages. ${ }^{62}$ For each entry, details are provided regarding the individual cadre's personal status, the status of family members, and urgent problems in need of attention. The spreadsheet records that over 1,200 cadres had lost their homes (this estimate is based only on the categories "without home," "homeless," and "collapsed house" and excludes categories such as "damaged" and "dangerous housing"). Under the "urgent problems in need of attention" section, "no money" and an inability to afford their child's school fees were listed almost ubiquitously. One cadre's situation is described as "no home, and wife currently in hospital with no one to look after her."

Cadres throughout the earthquake zone suffered from a combination of work pressure and personal tragedy. According to a social worker in Wenchuan county, "cadres confessed to me that they hoped to be dismissed from their jobs to relieve them of the pressure of working in the postearthquake areas." ${ }^{63}$ The social worker cited "too much work pressure and not enough time to grieve" as the most common complaints. It was also common among cadres to feel that their sacrifices were unappreciated by their intended beneficiaries. In the words of one cadre, "I've devoted myself totally to working on providing relief since the earthquake occurred. I haven't gone home for two weeks and I don't know when I can take a proper rest. We just work and work but many people still do not understand how hard it has been for us and they do not care either. They are simply being difficult." 64

A national spotlight was cast on the psychological conditions of local cadres in the earthquake zone after several of them committed suicide. The first case was the suicide of Dong Yufei, the director of Beichuan county's agricultural of-

61. Ibid., 281.

62. "Beichuan ganbu zhenhou shangwang fankuibao" [Postearthquake information report on the injury and death situation of Beichuan cadres], confidential party organization document.

63. Interview with NGO leader in charge of social work, Guangzhou, December 2012.

64. Chen Tao, "Social Workers as Conflict Mediator: Lessons from the Wenchuan Earthquake," China Journal of Social Work 3 (2009): 181. 
fice. ${ }^{65}$ His son had died when Qushan Elementary School collapsed, and although his wife survived, she was severely injured. In the account of a local witness, when Dong Yufei pulled the body of his son from the wreckage, he "held his son's lifeless body in his arms, faced the sky and wept bitterly, calling out his son's name and repeating over and over the phrase: please forgive Daddy, please forgive me." ${ }^{66}$ Without time to mourn the death of his child or to recover from his own injuries, Dong Yufei was immediately dispatched to work.

Almost a year after Dong Yufei's death, Feng Xiang, Beichuan county's propaganda department assistant, similarly committed suicide. ${ }^{67}$ Feng Xiang's son had also died when his elementary school collapsed. To assuage the spirit of his son, he wrote a poem that he posted online called "Child, there are no earthquakes in heaven." ${ }^{\prime \prime}$ In the poem, he addressed his son: "You lie in the ice-cold ground and I don't know if you are cold or not. Each day before dark, I worry that you are all alone, lying there, afraid."

\section{TAKING CARE OF THE SELF}

In the Mao era, complaints about mental or emotional problems were regarded as class based and in need of ideological correction. ${ }^{69}$ The ideology of Party spirit and organizational discipline are intentionally designed to suppress individual psychological needs and considerations. But in response to the high-profile suicides, the Party took an unprecedented step by applying psychological categories, explanations, and techniques to earthquake zone cadres.

Cadres showing signs of distress were allowed to go to a sanitarium to convalesce. In Beichuan county, the "Notice Concerning the Adjustment of Cadre Rest Schedules" stipulated that cadres should sleep in an extra hour Monday mornings, enjoy two day weekends, and leave work half an hour earlier every day. Additionally, a "compulsory holiday roster" was established to guarantee mandatory vacation times. ${ }^{70}$

65. "5.12 da dizhen hou 5 ge yue beichuan nongban zhuren zisha" [Five months after the 5.12 great earthquake Beichuan agricultural office director commits suicide], Huaxi dushi bao, October 8, 2008, http:// sichuan.scol.com.cn/dwzw/20081008/200810853617.htm.

66. Ibid.

67. "Dizhen zhounian ji, dangxin zisha fengchao laixi" [On the first anniversary of the earthquake, on the lookout for a wave of suicides], May 14, 2009, http://www.rdzx.net/xlzx/ShowArt.asp?id=114.

68. Feng Xiang, "Haizi, tiantangli meiyou dizhen" [Child, there are no earthquakes in heaven], Sina Weibo Blog, May 21, 2008, http://blog.sina.com.cn/s/blog_4fcbc32a01009a4u.html.

69. On depression and its relationship to politics in modern China, see Sing Lee, "Depression: Coming of Age in China," in Deep China: The Moral Life of the Person, ed. Arthur Kleinman et al. (Berkeley: University of California Press, 2011), 177-212.

70. Zhonggong beichuan qingzu zizhi xian wei bangongshi (Beichuan Qiangzu ethnicity autonomous county party committee office), "Beichuan ganbu ying zhen hou shou ge shuangxiu guanfang huiying dong yufei zisha" [Beichuan cadres welcome postearthquake first double relaxation: The official response to Dong Yufei's suicide], Guangzhou ribao, October 12, 2008, http://sichuan.scol.com.cn/dwzw/20081012/2008101293651.htm. 
Similar policies can be found in Wenchuan county's organization department 2010 end-of-year report. The section "Pay Attention and Care about Cadres' Physical and Mental Health" stipulated that work must not encroach on mandatory rest periods and alternating vacation shifts. The authorities in Abazhou Prefecture organized a trip for 30 prefecture-level cadres who received "commendations" to Sichuan's Jiuzhaigou nature preserve for "convalescence.” Wenchuan county also established an annual vacation rotation system and regularized work schedules for grassroots cadres engaged in reconstruction projects. Cadres who received "commendations" from the county Party and county government committees were rewarded with a week-long vacation. Township-level cadres, especially those who had "lost family members" during the earthquake, were to be transferred to county-level bureaus or relocated to townships near the county seat. ${ }^{71}$

Many cadres complained that in spite of the benevolent official policies, they were not able to take advantage of the two-day weekends, not to mention vacation time due to their onerous work burdens. A common refrain was that "work cannot be put down." In the weeks and months following the earthquake, the high frequency of severe aftershocks and mudslides prolonged the duration of the ongoing disaster. Cadres were responsible for relocating the displaced earthquake survivors into temporary housing before winter, which is brutally cold in this mountainous area of Sichuan. As was noted earlier, even after people's basic safety and needs were provided for, cadres were ordered to begin the building reconstruction process and complete it in less than two years. According to a leading cadre from Wenchuan county, "We continuously worked until 2011. Even though it was mandated to take a vacation, our cadres didn't have time to rest because our work wasn't finished." 72

At the provincial level, the Party School in tandem with the Party organization department held "psychological training classes" (xinli peixun ke) for over 200 cadres from villages in the earthquake zone. ${ }^{73}$ During these classes, Dong Yufei's suicide was examined and discussed as a "model case" of exhaustion from overwork and untreated post-traumatic stress. A psychologist from a hospital attached to Sichuan University warned: "Don't mistakenly believe that you can throw yourself into the most difficult work and challenging circumstances in order to leave behind the past and forget it."

During the same training session, cadres were asked to "write down their strong points" and were encouraged to "study how to view their real selves as ac-

71. Wenchuanxian ganbu duiwu zhuangkuang gongzuo huibao.

72. Interview with Wenchuan county leading cadre, Wenchuan county seat, March 2013.

73. Wu Chutong, "Yi Dong yu fei zisha wei jian: zaiqu ganbu 'xinling chongjian"” [The example of Dong Yufei's suicide: Disaster area cadres "mental health reconstruction”], Tianfu zaobao, October 22, 2008, http:// sichuan.scol.com.cn/dwzw/20081022/2008102252714.htm. 
ceptable." ${ }^{\prime 4}$ The punitive superego language of Party spirit was supplemented with a nurturing discourse of self-acceptance: "Even though everyone has flaws and is lacking in some way, we must optimistically improve ourselves." Before the training session concluded, cadres were urged to form conversation groups, pen pals, and support networks in keeping with their special identity as both Party cadres and disaster victims. This self-help discourse was supposed to encourage cadres to deal with their emotions in psychological rather than political terms. ${ }^{75}$

Beyond the earthquake zone, a sense of psychological vulnerability has emerged among cadres across China. According to a national survey conducted online in 2010 by sociologist Sun Liping, a majority of cadre respondents perceived themselves as belonging to a "marginalized and vulnerable group" (ruoshi qunti) an official sociological category typically applied to laid-off workers, migrant workers, and other disadvantaged groups. ${ }^{76}$ Cadres described a feeling of being squeezed between top-down pressure to display "political achievements" for their superiors and bottom-up demands to satisfy the needs of the people. Due to their constant exposure to scrutiny, respondents described themselves as "easily frightened" (figuratively described as a bird startled by the twang of a bow, jing gong zhi niao), "anxious," and "mentally and physically exhausted."

There has also been growing concern among Party leaders that cadre suicides are becoming a national problem. To understand better the psychological stress of lower-level cadres, Party leaders invited Peng Kaiping, a professor of psychology from the University of California at Berkeley, to the leadership compound in Zhongnanhai to offer a course on psychology. In a later interview, Peng argued that the majority of cadre suicides are related to their position in the political system. In the words of Peng, it is a system of "cruel competition for promotion" that isolates cadres from broader affective communities and networks of support: "There is no one to whom they can vent and say what is on their mind. There are some things they cannot say, some things they do not dare to say, and some things they are not willing to say. This creates feelings of depression and helplessness and the sense of being out of options."77

Peng also points to an enduring political culture and Maoist legacy within the Party, though he does not mention Mao or Maoism directly: "For a long time, we

74. Tao Ling, "Sichuan shouci jizhong dui zaiqu jiceng ganbu kaizhan xinli fudao" [Sichuan's first time carrying out psychological counseling focused on grassroots cadres], Huaxi dushibao, October 22, 2008, http:// sichuan.scol.com.cn/dwzw/20081022/2008102270004.htm.

75. For a fascinating perspective on "therapeutic governance" applied to laid-off workers from China's stateowned enterprises, see Jie Yang, Unknotting the Heart: Unemployment and Therapeutic Governance in China (Ithaca, NY: Cornell University Press, 2015).

76. Sun Liping, "Zouxiang jiji de shehui guanlu" [Trend toward proactive social management], Shehuixue yanjiu [Sociological studies], no. 4 (2011): 22-32.

77. Ibid. 
have looked at psychological problems [xinli wenti] as attitudinal problems [taidu wenti], ideological problems [yishixingtai wenti] and [political] consciousness problems [juewu de wenti].” In this passage, Peng tactfully recycles key terms from a Maoist vocabulary as antecedent conditions for the creation of a political ecology in which cadres "refuse to admit they suffer from depression," afraid it will be viewed as being "weak willed."

\section{CONCLUSION}

In 1968, when surveying the damage to Party authority being caused by the Cultural Revolution, Benjamin Schwartz asked, "Have the Maoists attacked the Party? What indeed is the Party as such? . . . To any genuine Marxist-Leninist, it is, of course more than its cell and anatomy. It is a metaphysical organism which is more than the sum of its parts."78 This article draws inspiration from Schwartz's willingness to reflexively question the fundamental political categories of Chinese politics.

This article has attempted to address the question, what is a Communist Party cadre? The Communist Party cultivates and invests the life of the individual cadre with its authority. Whereas the question of mandatory political education and indoctrination for leaders is not a feature of liberal democratic governance, in China's political system the cadre is a vital target of governance, training, and intervention. For these reasons, the ideal typology of the Communist Party cadre should not be conflated with the generic and vague categories of Weberian "bureaucrats,"79 "experts," are responsible for state administration and economic growth, as Party cadres they are also subject to a lifelong process of ideological training and organizational discipline.

The Party's organizational ethos of subordination and sacrifice is perfectly expressed in Liu Shaoqi's How to Be a Communist:

A Party member has interests of his own, which may be inconsistent with or even run counter to the interests of the Party in certain circumstances. Should this hap-

78. Benjamin Schwartz, “The Reign of Virtue: Some Broad Perspectives on Leader and Party in the Cultural Revolution," in Party Leadership and Revolutionary Power in China, ed. John Wilson Lewis (Cambridge: Cambridge University Press, 1970), 149-69.

79. Max Weber, "Politics as Vocation," in From Max Weber: Essays in Sociology, trans. and ed. H. H. Geerth and C. Wright Mills (New York: Galaxy, 1958), 77-97.

80. Joel Andreas, Rise of the Red Engineers: The Cultural Revolution and the Origins of China's New Class (Stanford, CA: Stanford University Press, 2009), 223.

81. Jean Oi, "The Role of the Local State in China's Transitional Economy," China Quarterly, no. 144 (1995): 1137.

82. Dali L. Yang, Remaking the Chinese Leviathan: Market Transitions and the Politics of Governance in China (Stanford, CA: Stanford University Press, 2004). 
pen, it is incumbent on him to sacrifice his personal interests and unconditionally subordinate them to the interests of the Party; under no pretence or excuse may he sacrifice the Party's interests by clinging to his own.... Hence a Party member can and must completely merge his personal interests with those of the Party.... It is all the more necessary for each cadre and leader of the Party to be a living embodiment of the general interests of the Party and the proletariat.

Liu argues that Party spirit requires the endurance of "humiliations without bitterness if the occasion so demands" 83 - which is the ultimate test of faith and devotion. ${ }^{84}$

In a China that has long since abandoned its revolutionary mission and ethos of class struggle, Liu's words seem to be from a bygone age. The stereotypical image of today's cadre is a most likely corrupt official wearing Louis Vuitton and certainly not an austere communist engaged in revolutionary struggle from a cave in Yan'an in the 1930s. I suggest however that Liu Shaoqi's words remain relevant for the simple reason that the Chinese Communist Party is still a Leninist party governed by ideology and organization. In quotidian circumstances, this point fades into the background only to reemerge during emergency situations, such as the Sichuan earthquake, and anticorruption campaigns in which targeted cadres appear in humiliating televised confessions (a formula in which the disgraced cadre apologizes to the Party for letting it down). In both cases, the individual cadre is sacrificed for the glory of the Party.

My argument that cadres are Party spirit made flesh does not mean that the flesh is healthy or saintly. As we have seen, in the aftermath of the earthquake, local cadres experienced physical exhaustion, anxieties, and nightmares. After several cadres took their own lives, the Party responded with a new therapeutic discourse addressing the psychological needs of the cadre as an individual. However, I suggest that psychological individualization of cadres can only be a temporary measure. The Party's logic of legitimation and discursive apparatus necessitates the exploitation of individual cadres in the name of Party spirit. The contradiction between the general needs of the Party and the individual needs of the cadre will always be resolved in favor of the former. Xi Jinping's anticorruption campaign is only the latest iteration of this logic.

$\mathrm{Xi}$ Jinping's goal is to revive the flesh of the Party-flesh that would not be inaccurately described as necrotic, considering that the Chinese word for corruption, fubai, is etymologically associated with "rotten meat." There is nothing new or shocking about Xi's objective or the tools he is using to pursue it. It is entirely consistent with the Party's discursive tradition of describing anticorruption and Party rectification as a hygienic and medical procedure. In the words of Liu Shaoqi,

83. Liu, How to Be a Good Communist.

84. In hindsight, this passage is heartbreaking. 
"as comrade Mao Zedong puts it, we must constantly 'sweep the floor and wash our faces' so as to prevent political dust and germs from clouding the minds of our comrades and decaying the body of our Party." ${ }^{\prime 5}$ Mao himself repeatedly extolled criticism and self-criticism as a processes of "treating the disease to save the patient" (zhi bing jiu ren) - a phrase that remains a Party axiom today. In a recent publication from the Central Party School, Xi's anticorruption campaign was compared to an "excision of evil, malignant tumors" in the organism of the Party. ${ }^{86}$

Although it is prudent for scholars to refrain from making grim or glowing prognostications about the fate of Communist Party, we can at least listen to how it is diagnosing itself. The source of the Communist Party's vitality is Party spirit, and it will employ whatever measures necessary to preserve it.

85. Liu, How to Be a Good Communist.

86. Huang Xianghuai, "Xin Jinping lun jiankang zhengzhi shengtai" [Xin Jinping's theory on healthy political ecology], Zhongguo gongchandang xinwen wang (Chinese Communist Party news website), June 3, 2015, http://theory.people.com.cn/n/2015/0603/c168825-27099150.html. 